\title{
DISPOSITION OF FEDERALLY OWNED SURPLUSES
}

\author{
Cuifton E. Macx*
}

INTRODUCTION

Recently a nationally known publishing service polled its business readers to determine which postwar problems were being given greatest thought and consideration. "Post-war jobs" was most frequently named; "federal surplus disposals" ran a close second.

This latter is indeed significant. On the one hand, it is comfortable to note that, of all the warring nations, only the United States remains so situated as to have surpluses amidst a world of general destruction and deficiencies. On the other, the nation is apparently soberly conscious of the fact that, comfortable though the thought of surpluses may be, full recognition must be given to the problems of their disposal.

Such surpluses are indeed inevitable. When asked if there was a method by which the United States could avoid them, a high ranking General replied: "Only if you fire the last cartridge in the nation, consume the last " $\mathrm{K}$ " ration in the Army, and wear out the last pair of boots on the precise hour of Victory."

Unlike the peacetime programming of supplies and equipment, the Government at war cannot indulge in "close" determination of what it might conceivably need. The presence of a surplus of supplies indicates the availability of enough supplies.

Eventually, however, this nation will have a prodigious amount of surplus war materials. Since that condition is unavoidable, it is then by no means premature to discuss the vital question of how to dispose of those surpluses. Some disposals are under way now. They will increase as time passes.

Only one note of caution should be interjected. Present discussion of the surplus property topic must avoid conveying a false impression of the current war needs. Every responsible authority insists that the need for substantial production and procurement still remains. In short, "the war is not over."

The paradox of relatively minor quantities of surplus materials developing in a period of intense war production can be easily traced and simply explained. Changes in war strategy, in the design of weapons, the termination of war contracts for

- L.L.B., Suffolk Law School, I927. Director of Procurement, United States Treasury Department. Lecturer on purchasing, American University. Member, Educational Committee, National Association of Purchasing Agents. Member, Board of Directors, American Standards Association. Member, Soviet Protocol Committee. Member of Maine Bar. President, Washington Association of Purchasing Agents. Formerly with Bureau of Internal Revenue, 1926-41. Author, Federat Procurement. Contributor of articles on procurement. 
these and other reasons, and the production of new products-all these can and do affect supply requirements and, thus, development of surpluses.

For example, certain of the Government-built explosive plants are not needed at the present time because of changes in technical development and in the course of the war. Similarly, the fact that the Government recently halted production of a certain type of ammunition, thus making momentarily idle I,500 skilled workers and throwing quantities of brass, steel and gunpowder into a temporary surplus category does not mean a decline in the need for manpower, brass, steel and gunpowder. Or for hand grenades, tanks, aircraft or torpedoes. The workers and materials affected have already been absorbed into other equally essential war requirements. Currently then, proper control of surpluses requires a carefully conducted management operation to effect a shifting and transfer of what is surplus in one place to where it is critically needed in another. When the time comes that such shifts are not necessary, as needs lessen, the heaviest surplus disposal task will be at hand.

Rather substantial preparations to handle the problem have already been made. These will be discussed in this article, beginning with the experience of the First World War and progressing chronologically to events as they stand today.

\section{RECORD OF WORLD WAR I}

In order to gain perspective, and that we might strive to avoid previous errors, a review of the surplus disposal procedures employed following World War I is profitable.

Compared to the scope and intensity of the current struggle, the First World War was relatively small. Procurement programs in effect today are ponderously greater than those of I9I7-I8. Although it need not necessarily follow that the impending surplus stockpile, because of greater World War II purchases, will be proportionately as great over the last war, it is safe to predict that it will be sizably larger than before, and certainly of much more complex character.

For example, holdings by the Government of war plants are now approximately 25 times larger than they were in 1918 , a statistic to be separately discussed. Too, a great bulk of individual items of this war which may become surplus are much more costly and less adaptable to peacetime pursuits than those arising out of 1918 . Probably the most expensive land weapon employed in World War I was an armored locomotive-much more adaptable to peacetime and less expensive than a super bomber, which requires a single outlay of approximately one-half million dollars-not to speak of the B-29.

Even so, the diversity of surpluses in the last war was interesting and large. The following partial list of surplus stocks indicate the variety:

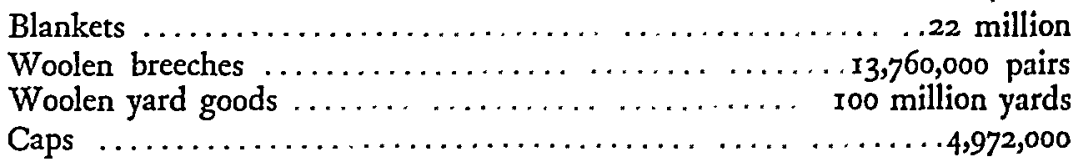




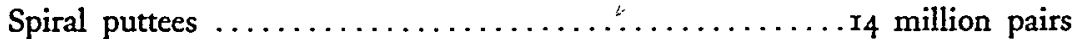

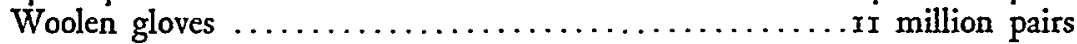

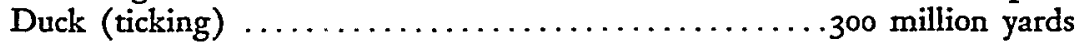

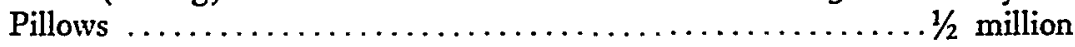

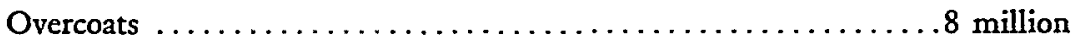

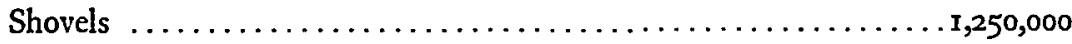

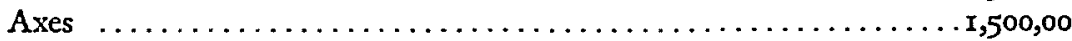

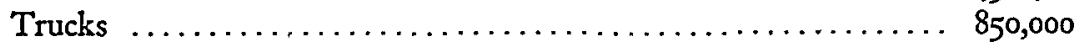

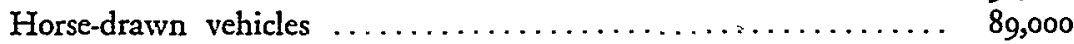

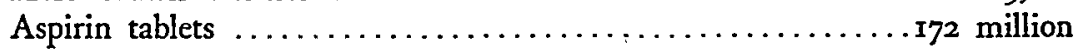

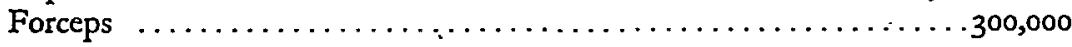

There is no information available which indicates that the Government, prior to the Armistice, worked out definite methods for use in disposing of surpluses. Peace loomed suddenly, as did the question of property disposition. Property officers themselves acted independently in decisions affecting property disposal. This applied to the armed services and to the civilian agencies as well.

It was not until January 4, I9I9 that the War Department established a coordinating office-the Director of Sales. The Director was empowered to supervise sales methods, prices, advertising and centralization of records on the disposal program, and to report directly to the Congress.

Similar central coordinating offices were then established within the Navy Department and the U. S. Shipping Board. A complete control was finally established in July of I92I, when the Office of the Chief Coordinator was established.

A graphic picture of disposals is lacking, largely due to the fact that an adequate system of reporting or classifying the goods was never instituted. This defect alone would have prevented any truly effective coordination of the selling program. The exact results of the program were:

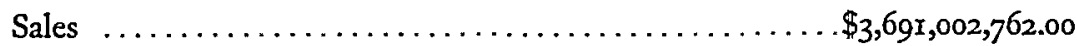

Transfers to Gov't Agencies ................... 555, 959.34

Total ................................. $\$ 3,691,557,957.34$

Through retail stores, surpluses were for many years available for sale to the public.

\section{Executive ORDer No. 9235}

Discussion of the above named Order may serve as a convenient focal point about which to introduce a picture of Federal property operations during the first two years of the current war.

By mid-year 1942, despite unparalleled increases in direct war production and diminishing civilian-goods manufacture, war needs still demanded a substantial part of available supplies. Materials, facilities, and labor were applied singularly to the war task. The reigning philosophy in distributing the fruit of their efforts was simply expressed: Direct war needs must come first, irrespective of any other consideration. 
Under such an implacable program, requirements of the civilian agencies of the Federal Government were accorded no special consideration in allotments of remaining goods. Those items carrying a priority as prerequisite to purchase were unavailable to the Federal agency which could not show eligibility identical to that required of any other potential customer.

As a result, a "make it do" policy on the use of Government facilities was inevitable. Thus, fullest utilization of Government-owned property was the important immediate objective of Executive Order No. 9235, effective October 16, r942. It is, however, valuable on a long-range basis because it is good business. The Order is additionally significant in that it resulted, for the first time, in a requirement that Federal agencies located outside the District of Columbia shall pay the value of such surplus goods obtained from the Procurement Division. Proceeds are credited to the Treasury (except where the appropriation in question requires that the proceeds be credited to that appropriation).

The Order defined "government agency" to mean: ". . . any executive department, independent establishment, agency, commission, board, bureau, division, administration, service, or office of the Executive branch of the Federal Government, including any independent regulatory commission or board and any Government-owned or Government-controlled corporation."

The Order also defined supplies and equipment:

“. . . any and all supplies, equipment, machines, commodities, accessories, parts, assemblies, or products of any kind in the possession of any Government agency, whether new or used, in use or in storage: Provided: that supplies and equipment which the Director of the Bureau of the Budget determines to be within the following categories shall not be subject to this order: (I) tactical supplies and equipment of the War Department, the Navy Department, or the U. S. Maritime Commission, (2) food and clothing, (3) construction materials acquired for the maintenance or construction of housing, electric power works or facilities, roads, reservoirs, or other physical improvements, (4) supplies and equipment acquired by any Government agency for transfer or export to any foreign government, and (5) supplies and equipment acquired from foreign or domestic sources for stock piling in connection with the war."

With the issuance of the Order, the Bureau of the Budget required Executive Departments to review their existing inventories of supplies and to classify them in the following four groups:

r. Necessary to the current prosecution of functions, activities or projects;

2. Stand-by for repair, replacements and anticipated expansion;

3. Temporarily idle because of project specifications;

4. Surplus to the needs of the function, activity or project for which acquired.

Concurrent with such classification, the Bureau of the Budget banned new purchases of many items widely used in the Federal service. Surpluses of a wide variety were reported to the Procurement Division and transfers effected to other Departments as needs arose. 
The War Department undertook its own similar review of military procurement programs. It formalized and publicized detailed instructions for the utilization and disposition of War Department property. Procurement Regulation No. 7 of the War Department contained detailed procedures for handling five classes of surplus industrial property:

I. Critical equipment and components.

2. Constructions equipment. basis.

3. Other equipment and industrial property requiring redistribution on a national

4. Controlled materials.

5. Other property which may be distributed on a regional basis. ${ }^{1}$

Component units of the War Department determined their own surpluses, circularized information concerning them to other divisions of the War Department. If no need was found within the Department, lists were referred to both the Procurement Division and to the War Production Board. Within twenty days, both agencies attempted to locate an essential war need for the property. Meanwhile, the War Department held the property ready for any need of its own which might suddenly develop.

If, at the end of the twenty-day period, the property was still available, any construction material was transferred to the Procurement Division. W.P.B. was notified of surplus critical materials, components and of controlled materials in the inventory. Property in classes (3) and (5) were, under some circumstances, disposed of directly by the War Department to private industry. In other cases, surpluses were declared to the Procurement Division.

An additional organizational development was the esablishment within W.P.B. of the Redistribution Division. Its function is to assist in quick and effective redistribution of surpluses. Members of the staff, located throughout the country, receive information as to the urgent needs of war industries and civilian economy. At the same time, surpluses held by either the War Department or Procurement Division were made known to the Redistribution Division, which was in such instances a "broker without fee." Resultant property sales were made direct to the buyer considered to have the most urgent (war connected) need.

Neither the Navy Department nor Maritime Commission have published formal regulations corresponding to War Department Procurement Regulation No. 7 . Surpluses accruing from these sources will, in all probability, come somewhat later than those expected from the War Department.

\section{The Surplus War Property Administration}

The Surplus War Property Administration, established February 19, I944 by Executive Order No. 9425 is today the Federal Government's instrumentality to deal with the problem of surplus disposals. In following this outline, the reader

\footnotetext{
${ }^{1}$ For recent changes in PR 7, see Christoffer, Disposal of Contractor-owned Property on Termination. infra, pp. $646 \mathrm{ff}$.
} 
should understand that final policy decisions and a permanent disposal structure are topics awaiting Congressional action.

Duiring r943, Messrs. Bernard M. Baruch and John M. Hancock launched a study of the entire demobilization question. On February 15, 1944, their now nationally known "Report on War and Post-War Adjustment Policies" was placed in the hands of War Mobilizer James F. Byrnes. That Report clarified the demobilization task as breaking into three major segments, namely: Contract Termination; Surplus Property Disposal; The "Human" Side of Demobilization (jobs, placement of veterans, etc.).

On the surplus property issue, the Report made specific recommendations as to the organization needed for disposal operations, and the business philosophy to be followed in making disposals. These were adopted without exception in the Executive Order establishing the S. W. P. A.

To head the Surplus War Property Administration, the Report called for "... a man of proven executive ability and business sagacity. ..." Mr. Will Clayton, former Assistant Secretary of Commerce and a man of wide commercial experience, was named to the post.

". . . To advise and assist him (The Administrator) in developing unified policies for all Government agencies ..." the Report recommended, and the Executive Order established, a Surplus Property Policy Board. With the Administrator as Chairman, the Board consists of one representative each from: War, Navy, Treasury, R. F. C., Maritime Commission, W. P. B., Bureau of the Budget, War Food Administration, Attorney General, Federal Works Agency, State Department, Foreign Economic Administration.

Neither the Board nor the Administration is an operating agency. Neither owns property, nor sells it. The concern is centered directly on the matter of policy to be followed in surplus disposals; the exercising (by the Administrator) of a broad and general control over the main course or direction of the flow of surplus property. In accordance with the letter of the Baruch-Hancock Report, and repeated statements by Mr. Will Clayton, the Administration's relation to those agencies actually disposing of property will be on a policy level, and a policy level only. The Board members, appointed by their respective Department heads, are "... men who can see that the policies agreed upon by the Board are carried out in their own agencies. ..."

Clearly defined major disposal outlets are named to carry out the actual disposal operation. The majority of surpluses will be handled according to the following classifications:

Capital and producer's goods, by a central corporation within the R. F. C.

Consumer goods (other than food), by Procurement Division of the Treasury Department.

Ships and maritime properties, by the Maritime Commission.

Food, by the War Food Administration. 
Surpluses located outside the continental limits of the United States are to be handled by the Foreign Economic Administration.

Since it is true that a careful examination of the Baruch-Hancock Report is required reading for anyone desiring full understanding of the present organization, it is from that source that there is taken a succinct picture of what the Surplus War Property Administration and the disposal agencies are presently striving to accomplish in sales:

"Our suggestions to the Surplus Administrator can be summed up in these ten. basic principles:

I. "Sell as much as he can as early as he can without unduly disrupting normal trade.

2. "Listen to pressure groups but act in the national interest.

3. "No sales, no rentals to speculators; none to promoters.

4. "Get fair market prices for the values with proceeds of all sales going to reduce the national debt.

5. "Sell as in a goldfish bowl, with records always open to public inspection.

6. "As far as is practicable, use the same regular channels of trade that private business would in disposing of the particular properties.

7. "No Government operation of surplus war plants in competition with private industry.

8. "No monopoly; equal access to surpluses for all businesses; preference to local ownership, but no subsidizing of one part of the country against another.

9. "Scrap what must be scrapped, but no deliberate destruction of useful property.

I0. "Before selling surplus equipment abroad, assure America's own productive efficiency on which our high wages and high living standards rest."

As of the present writing, the Surplus War Property Administration is pursuing a course aligned to these ten recommendations. On May 15, 1944, the S. W. P. A. issued its Regulation No. I, the chief purpose of which was to clearly distinguish exactly what types of potential surpluses were either "consumer goods" or "producer's goods" or within other classifications, and to assign those types to the proper agency for disposal.

\section{Current Disposals of "Consumer Goods"}

Of all the realm of surpluses, none has more potential customers than "consumer goods." This term embraces within its meaning the majority of the finished packaged, ready-to-use items which the consumer obtains in the retail market. ${ }^{2}$ The term includes radio broadcasters, photographic projectors, trucks and packaged medicines. It includes the jeep, about which much of the public conception of postwar Government surpluses revolves. It includes a total of 83 categories of goods.

Although not yet developed in any appreciable quantity, such surpluses have on occasion been available for public sale. In these instances, most of them since the

\footnotetext{
${ }^{2}$ Sec S. W. P. A. REG. I, of May 8, r944, for designation of commodities to be classed as consumer goods for disposal purposes.
} 
beginning of this year, sales have been made in strict accordance with the policy of "sale through regular trade channels." Surplus shoes have been offered and sold to the shoe industry. Surplus motor trucks have been sold to franchised dealers who, in turn, sold to consumers.

In addition to following the "trade channel" policy, the Procurement Division's disposal activities have been made in strict accord with all governmental materials controls. No surpluses can be sold in excess of ceiling prices; nor in violation of WPB allocation orders. Any governmental regulation affecting the sale or transfer of property must be observed.

At the present time, sales of surpluses are made on an "as is, where is" basis. The matter of extending credit to such organizations is also suggested as one measure of further applying close cooperation between customer and seller in the disposal task. These questions are at the present time under study by the Surplus War Property Administration.

\section{When Will Surpiuses Deveiop?}

Development of methods for uniform and efficient disposal of surpluses now and after the war requires a reasonable guess at the answer to the question of when such surpluses will actually be in hand. The following analysis is, of course, open to question. However, it now appears that surpluses will become available in three fairly distinct phases:

I. A period of release of supplies, materials and equipment during the war. This is currently the case.

II. A period when large amounts of supplies, equipment and materials and possibly some war plants will be released because of complete victory over one of our enemies.

III. The postwar period when it will be necessary to dispose of tremendous quantities of supplies, equipment, materials and real property as well.

There are indications that surpluses developing in each of these "periods" will be greeted by somewhat different general conditions. For example, there is today a definite and chronic shortage of almost every type of civilian goods. The demands for supplies are substantial-a fact attested to by the heavy volume of correspondence and interest exhibited each time the Procurement Division of the Treasury Department, through any of its Regional Offices, is able to make available for sale any amount of goods.

However, generally speaking, until early 1944 most of the surpluses accruing were not for sale to the public. They were instantly put to use in another phase of the war program. Demand far exceeded available supply. Of approximately I30 million dollars worth of property channeled through the Procurement Division from July I, I 943 to May 3I, I 944 only about five million went to civilian con. sumers. The vast majority of such goods was transferred to the armed services, other war agencies, to satisfy Lend-Lease requisitions or sold to war contractors. Surpluses deriving from contracts now being terminated are, to the extent possible, immediately being applied to other war needs. Summing up, current surpluses 
have not thus far begun to ease the shortage in civilian goods. Overall demands of war must still come first.

Surpluses arriving in the second period described will require different handling. If one enemy collapses there is certain to be a tremendous overhauling of the entire war program. Large quantities of goods may suddenly become surplus. Certain war plants will undoubtedly shut down-the number and nature of such plants being still unpredictable. There will exist the possibility of a substantial contribution to satisfy civilian demands. War manufacturers will be making efforts to reopen their plants on a peacetime basis; to re-employ idle war workers. Indiscriminate release of surpluses by the Government would rob the buying market of some power, thus impeding general economic reconversion. What selling is to be done must be done with the following principal objectives uppermost in mind:

I. To so distribute goods that re-employment in peacetime activities will be aided.

II. Recovery by the Government of as much return as is possible within the limits set by (I).

For the purposes of discussion, it may be said that the Armistice will at once bring on the most interesting, and the most critical period of surplus property accrual and disposition. A major portion of the remaining war contracts will be cancelled, and industry will be making every effort to get back into peacetime production. Concurrently, astronomical amounts of equipment, materials and supplies will suddenly be surplus. War plants, having fulfilled their immediate objective, will await disposal.

An immediate inventory of existing surplus equipment, materials and supplies will be required. Types of surpluses will be divided into two groups.

First, there will be the surpluses of completed goods delivered to the Government and stored in warehouses, depots, bases, and at other locations. Second, there will be the goods physically located in the plants of manufacturers whose contracts are being terminated. The second classification of surpluses will most urgently require attention.

This classification will consist all the way from materials bought and stored for the production of Government contracts, to finished items ready for shipment. The contractor's funds-money he will quickly need to convert to peacetime production-will be tied up in such inventories. Swift liquidation of the contractor's investment will be of the most crucial importance.

Specific solutions will be required for specific cases, but the keynote for such solutions should be speed of action to release capital, space, facilities and other elements necessary in converting to peacetime production. ${ }^{3}$

Other inventories will be those actually owned by the Government and already in storage. These will be heavy in volume. They will require careful management, an administration designed to avoid "dumping" on the market, to avoid

\footnotetext{
${ }^{3}$ See in this connection, Christoffer, Disposal of Contractor-owned Property on Termination, in this
} symposium, infra, p. 646 . 
ill-advised and ill-timed sales conflicting with a struggling industry's efforts to get back into business. Potentially, this stockpile could be dangerous-but it need not be.

The stockpiles of Government-owned goods immediately following the war will be available to minimize dislocations and even actually to provide established concerns with materials they will quickly need; materials which they originally sold the Government.

\section{Recording and Reporting of Surpluses}

A necessary preliminary step in disposition of surpluses is the assembly of a complete inventory. Because such an inventory is also of value to the Federal Government in handling its normally used property, work toward standard inventory methods has already been carried forward to a considerable extent.

Under Executive Order 9235, Government agencies were required, after a survey of their equipment, to declare all surpluses to the Procurement Division of the Treasury, with the exception of certain commodities previously mentioned.

The Procurement Division was then responsible for effecting transfers to other Federal agencies, or sales to non-Federal agencies (such as States and counties) and also for effecting sales to war contractors and to the general public. These operations required that the Procurement Division, upon receipt of surpluses, should appraise, classify and record preliminary to disposition.

To facilitate the handling of surpluses, the Procurement Division established eleven Regional Offices and operated on a decentralized basis. Agencies declared surpluses to the Procurement Division Regional Director having jurisdiction over the area in which goods were located.

The entire operation requires a uniform system of nomenclature, so that like items declared to various field officers can be uniformly recorded, classified and catalogued for whatever disposition is intended. Necessarily, the system must be allencompassing. When postwar surpluses develop, property officers receiving them can, in a word, expect to see almost anything. The imagination cannot begin to explore the number and types of goods in current inventories. Too, not only must there be uniform recording of like items-but a system wherein like groups of items can be brought together in a logical aggregation.

As a measure of the complexity of the potential inventory, there can be cited the Federal Standard Stock Catalog. This is a system for identifying by number and description all of the items which Government uses. It encompasses at the present time approximately one million different items. The Federal Standard Stock Catalog is designed to distinguish minute differences between items for the purpose of procurement, storage and issue. Such a work is in considerably greater detail than would be feasible for inventorying surplus property. The instrument presently being developed, while not approaching the detail of the Federal Standard Stock Catalog, is nevertheless being designed to record and classify surplus property in adequate detail. 
The Government has had a number of classification systems for various purposes. Not until 1942, however, had there existed any system which even nearly approached the needs of the surplus property program. As a result of collaboration between the Bureau of the Budget, the Procurement Division of the Treasury Department and the War Production Board, together with a number of other governmental agencies, there was issued Technical Paper No. 26, Standard Commodity Classification.

This system combines related products into consistent and logical groupings of commodities. It has three main divisions: I. Crude materials, including commodities of animal, vegetable and mineral origin. 2. Basic materials and products, including semi-finished and fabricated materials to be used in further manufacturing or construction. 3. End products. Using this classification as a basis, and with the collaboration of the same groups which developed it, the Procurement Division is adapting and amplifying Technical Paper No. 26 and adding units of measure to produce a surplus property classification.

One of the difficult (and interesting) problems encountered, has been the development of an index for the use of the classifying officers in the field. The fundamental purpose of such an index is to assist the property officer in the field to determine quickly into what category of the classification code any given item of property should be placed. It is necessary that the index be sufficiently all-inclusive, so that items will always end up in the same classification no matter in what way a piece of surplus property is described when it is turned over to the Procurement Division.

An index to accomplish these purposes is being prepared, and as sections of the adapted classification and the index are completed, they are sent out to the field offices of Treasury-Procurement, where field office records are then converted to conform with the system. Ingenious methods have been employed to utilize punch card machines to record the classification code and the index so that, as new sections are completed, quick re-runs of the total code and index may be made. Re-runs are then duplicated by a photo offset process, providing an economical and quick method of superseding all previous issues with a complete new issue.

\section{War Plants-A Separate Problem}

The Government of the United States, for the purpose of increasing war production, has invested in plants and plant facilities to the extent of more than fourteen billion dollars.

The immensity of this figure becomes even more obvious when this illustration is offered: It has been reported that approximately one-fifth of the total national investment in production facilities is Government owned. Ownership is vested principally in the Reconstruction Finance Corporation and its main subsidiary, the Defense Plant Corporation. Other owners are War and Navy Departments and the Maritime Commission. 
The demobilization and disposal of these enormous assets will invariably have a profound effect on the economic welfare of the United States. Many of the perplexing problems likely to arise are already under intense study.

A very condensed table of Government holdings is offered to reveal the basic nature of the industries involved:

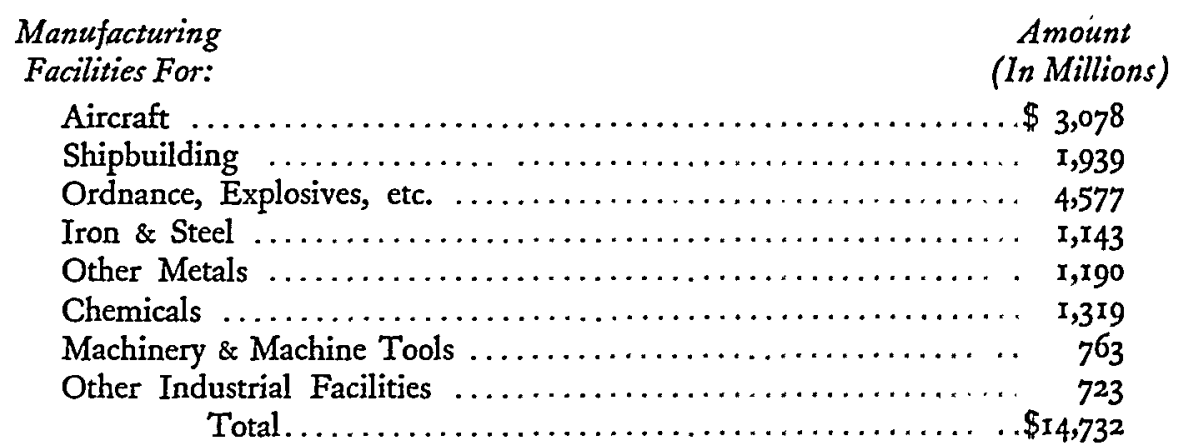

Additional pertinent facts make Government holdings even more important. The Government holds a dominant position in many fundamental industries. It is in possession of ninety percent of all production facilities in the aviation industry. It owns almost all magnesium plants; its investments in shipbuilding facilities have increased the production capacity of that industry to approximately thirty-three times the pre-war level. Further, its involvement in industries likely to become of major importance after the war is equally heavy, or heavier. The Government owns all synthetic rubber plants and many establishments producing electronics devices destined to become widely used in general civilian life. The Government's position in these industries obviously raises many questions, chiefly economic and financial, which must be considered in the post-war disposal of plants.

The more obvious questions to be answered in connection with plant disposal are already under active study. For example, the question of just how much of the total available will actually be surplus is a vital issue. Certainly, if a large stand-by Army is maintained for several years after the peace, the supporting elements will also have to be maintained-explosive plants, arms producing establishments and other works not easily converted from peace to war production. Similarly, the record breaking Navy now produced and constantly being enlarged will require repair facilities on a grand scale and plants manufacturing replacement items. In this same connection, the merchant marine fleet will make necessary the maintenance of many establishments and installations.

Obvious questions now under study include: What is to be done with the new industries created (synthetic rubber, for example)? Who shall gain control of Government-built pipe lines? What policy shall be adopted on the matter of allowing new and untried capital into industries in which they previously have had no experience?

Final decisions as to the disposal of any single plant (and the Defense Plant Corporation is reported to hold $\mathrm{x}, 666$ ) would require thorough-going and detailed 
studies of the post-war markets in which it would operate, the effects of alternative types of sales on the portion of the industry not controlled by Government, and the indirect effect of its operation on competitive industrial groups. The method of large scale dispositions of these investments, either war plants or supplies, equipment and materials is being considered by Congress.

On one point of the entire surplus disposal problem all authorities are unanimously agreed: That the disposal policy should take into account the welfare of the entire country. The disposal of billions of dollars worth of facilities, ranging from flying schools to ice houses, should be done in a manner to encourage private operators and private business. How this can best be done involves the complex questions of financing, degree of control to be retained by the Government, and method of selecting purchasers. These questions are being carefully studied.

The uncertain and changing fortunes of war have thus far precluded the working out of greatly detailed plans for the disposal of war plants. At the same time, however, the factors most dominant in such mass quantity disposals are being recognized and authoritative suggestions are being presented to Congressional committees studying the whole disposition task. Thus far, in the neighborhood of 30 Bills or Resolutions that in one way or another touch upon some aspects of the general problem of property disposal have been introduced. ${ }^{4}$ This lively interest indicates that comprehensive or piecemeal legislation will soon be enacted-indeed, may be enacted before this is published. ${ }^{5}$

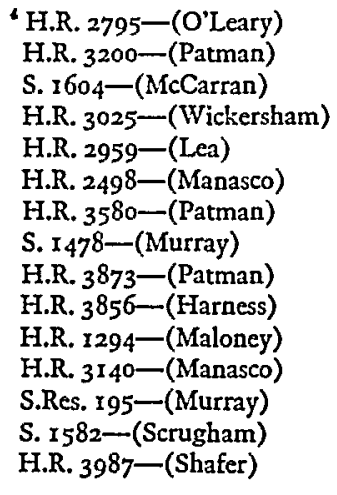

H.R. 4009-(Starnes)

S. I609-(Murray)

H.R. 4043-(Gathings)

S. $\times 680-$ (Nye)

S.Con.Res. 33-(Davis)

S. I730-(George and Murray)

S. r7r8-(Murray and Gearge)

S.Res. I02-(George)

S. 1727 -(Gillette)

S. I729-(Holman)

S. $\times 745$-(Hatch)

H.R. 4420-(Patman)

S. I823-(O'Mahoney)

S. I 815 -(Clark)

H.R. $4789-$ (Walter. House version of S. $x 7$ I8)

'Since this was written, the Contract Settlement Act of 1944 was approved July I, I944, being S. I71 8 as modified. The only aspect of property disposal touched upon in the Act is the removal and storage of termination inventory not retained or sold by the war contractor. See following article, this symposium. [ED.] 